VILNIUS GEDIMINAS TECHNICAL UNIVERSITY

Loreta KELPŠIENE

\title{
CONSTRUCTION MODELLING IN ENVIRONMENT OF ECONOMIC RECESSION
}

\author{
SUMMARY OF DOCTORAL DISSERTATION \\ TECHNOLOGICAL SCIENCES, \\ CIVIL ENGINEERING (02T)
}

Vilnius TECHNIKA 2011 
Doctoral dissertation was prepared at Vilnius Gediminas Technical University in 2007-2011.

Scientific Supervisor

Prof Dr Habil Artūras KAKLAUSKAS (Vilnius Gediminas Technical

University, Technological Sciences, Civil Engineering - 02T).

The dissertation is being defended at the Council of Scientific Field of Civil Engineering at Vilnius Gediminas Technical University:

Chairman

Prof Dr Saulius RASLANAS (Vilnius Gediminas Technical University,

Technological Sciences, Civil Engineering - 02T).

Members:

Assoc Prof Dr Jurgita ANTUCHEVIČIENĖ (Vilnius Gediminas Technical University, Technological Sciences, Civil Engineering - 02T),

Prof Dr Birutė GALINIENE (Vilnius University, Social Sciences, Economics - 04S),

Prof Dr Habil Henrikas PRANEVIČIUS (Kaunas University of Technology, Technological Sciences, Informatics Engineering - 07T),

Prof Dr Povilas VAINIŪNAS (Vilnius Gediminas Technical University,

Technological Sciences, Civil Engineering - 02T).

Opponents:

Assoc Prof Dr Audrius BANAITIS (Vilnius Gediminas Technical University, Technological Sciences, Civil Engineering - 02T),

Assoc Prof Dr Stasys Albinas GIRDZIJAUSKAS (Vilnius University, Social Sciences, Economics - 04S).

The dissertation will be defended at the public meeting of the Council of Scientific Field of Civil Engineering in the Senate Hall of Vilnius Gediminas Technical University at 10 a. m. on 13 June 2011.

Address: Saulètekio al. 11, LT-10223 Vilnius, Lithuania.

Tel.: +370 5274 4952, +370 5274 4956; fax +370 5270 0112;

e-mail: doktor@vgtu.lt

The summary of the doctoral dissertation was distributed on 12 May 2011.

A copy of the doctoral dissertation is available for review at the Library of Vilnius Gediminas Technical University (Sauletekio al. 14, LT-10223 Vilnius, Lithuania).

(C) Loreta Kelpšienè, 2011 
VILNIAUS GEDIMINO TECHNIKOS UNIVERSITETAS

Loreta KELPŠIENÉ

\section{STATYBOS MODELIAVIMAS EKONOMINIO NUOSMUKIO APLINKOJE}

DAKTARO DISERTACIJOS SANTRAUKA

TECHNOLOGIJOS MOKSLAI, STATYBOS INŽINERIJA (02T)

Vilnius TECHNIKA 2011 
Disertacija rengta 2007-2011 metais Vilniaus Gedimino technikos universitete. Mokslinis vadovas

prof. habil. dr. Artūras KAKLAUSKAS (Vilniaus Gedimino technikos universitetas, technologijos mokslai, statybos inžinerija - 02T).

\section{Disertacija ginama Vilniaus Gedimino technikos universiteto Statybos} inžinerijos mokslo krypties taryboje:

Pirmininkas

prof. dr. Saulius RASLANAS (Vilniaus Gedimino technikos universitetas, technologijos mokslai, statybos inžinerija - 02T).

Nariai:

doc. dr. Jurgita ANTUCHEVIČIENĖ (Vilniaus Gedimino technikos universitetas, technologijos mokslai, statybos inžinerija-02T),

prof. dr. Birutė GALINIENĖ (Vilniaus universitetas, socialiniai mokslai, ekonomika-04S),

prof. habil. dr. Henrikas PRANEVIČIUS (Kauno technologijos universitetas, technologijos mokslai, informatikos inžinerija-07T),

prof. dr. Povilas VAINIŪNAS (Vilniaus Gedimino technikos universitetas, technologijos mokslai, statybos inžinerija - 02T).

Oponentai:

doc. dr. Audrius BANAITIS (Vilniaus Gedimino technikos universitetas, technologijos mokslai, statybos inžinerija - 02T),

doc. dr. Stasys Albinas GIRDZIJAUSKAS (Vilniaus universitetas, socialiniai mokslai, ekonomika - 04S).

Disertacija bus ginama viešame Statybos inžinerijos mokslo kryptie tarybos posèdyje $2011 \mathrm{~m}$. birželio 13 d. 10 val. Vilniaus Gedimino technikos universiteto senato posèdžių salèje.

Adresas: Sauletekio al. 11, LT-10223 Vilnius, Lietuva

Tel.: (8 5) 274 4952, (8 5) 274 4956; faksas (8 5) 270 0112;

el. paštas doktor@vgtu.lt

Disertacijos santrauka išsiuntinèta $2011 \mathrm{~m}$. gegužès $12 \mathrm{~d}$.

Disertacija galima peržiūretti Vilniaus Gedimino technikos universiteto bibliotekoje (Saulètekio al. 14, LT-10223 Vilnius, Lietuva).

VGTU leidyklos „Technika“ 1885-M mokslo literatūros knyga

(C) Loreta Kelpšienè, 2011 


\section{Introduction}

Research Problem. The research problem covers assessing the implementation of construction projects in environment of economic recession, as well as determining the best methods and measures, which construction companies willing to survive and sell their products or services ought to use, with the help of information and intelligent technologies.

Research Relevance. Different level factors that may be grouped in a variety of ways affect construction. A model of construction in environment of economic recession and innovations:

- help stakeholder groups (investors, contractors, suppliers, national authorities, users, etc) name and describe the environment of construction;

- help assess the feasibility of projects and make decisions;

- help determine the riskiest factors with negative effects on performance in construction and take up timely preventive measures; they also help assess the most promising or riskiest areas for corporate activities or expansion;

- help mitigate stress in labour relations and improve the efficiency of labour and investments.

Research Object. The object of this research are factors affecting construction at national, social and corporate levels, the stakeholder groups involved and their goals.

Research Goal. The research aims to develop a model of construction in environment of economic recession and an intelligent system based on the model. It also aims to assess and describe construction trends with the help of the developed model of construction in environment of general economic distress, as well as to develop the recommendable decision support system for construction based on the multiple criteria analysis method and multiple criteria variant design method.

Research Tasks. The following tasks are set to achieve the goal:

1. To analyse methods, models and intelligent systems available worldwide. To analyse Lithuanian and foreign experience related to construction decisionmaking in environment of economic recession using state-of-the-art online, intelligent and other technologies and innovations (Chapter 1).

2. To develop a model of construction in environment of economic distress.

3. To develop a criteria system for comprehensive description of the environment of construction in times of general economic distress (Chapter 2).

4. To use the model of construction in environment of economic recession in practical applications (Chapter 3).

5. To do multi-variant design and multiple criteria analysis of the environment of construction in times of general economic distress (Chapter 3). 
6. To develop, based on the model, the recommendable intelligent system for construction in environment of economic recession (Chapter 4).

7. To determine the best methods and measures, which ought to be used by construction companies willing to survive and sell their products or services in environment of general economic recession (Chapter 4).

Research Methodology. The research methodologies rest on the analysis of the research done by Lithuanian and foreign scientists in the field. The multiple criteria methods developed by E. K. Zavadskas and A. Kaklauskas were used and adjusted in the research; information technology, the principles of analogy, methods of comparative analysis, logics and synthesis were used as well.

The research is based on academic publications by Lithuanian and foreign authors, statistical publications, online statistical data of various countries, other academic and information publications by Lithuanian and foreign academic institutions.

\section{Original Scientific Contribution and Significance of the Research}

1. An original multiple criteria model of construction in environment of economic recession (CEER) was developed and its components discussed in detail.

2. Available project multi-variant design and multiple criteria analysis methods were adjusted for the above model; the methods were improved and helped to make integrated assessment of the model's economic, technical, qualitative and other aspects.

3. Macro, meso and microenvironment factors pertaining to CEER were described in detail. The impact of the factors on CEER was illustrated.

4. The model of construction in environment of economic recession was used in practical applications.

5. A thorough criteria system to describe the environment of construction in times of economic recession was built.

6. A detailed database to describe the environment of a construction project in times of economic recession was built.

7. The recommendable intelligent system for the environment of construction in times of economic recession was developed.

8. The developed intelligent multi-variant decision support system for the environment of construction in times of economic recession was used in practical applications.

Practical Significance of the Research Results. An original recommendable system for the environment of construction in times of economic recession was developed; it may facilitate efficient management decisions in construction projects. The system might be helpful to many stakeholder groups: investors, contractors, manufacturers of building materials, designers, users, etc. 
The main propositions of the dissertation were discussed in one scientific conference and one colloquium. The material of the dissertation was published in five scientific articles. The research results were incorporated into the syllabus (Construction Business) for MA students majoring in construction management in Šiauliai University.

\section{Defended Propositions}

1. The developed model of construction in environment of economic recession helps to make adequate descriptions of stakeholder expectations and the construction market, as well as of the entire macro, meso and microenvironment that affects the stakeholders. It also helps to make efficient decisions.

2. The developed database of construction in environment of economic distress facilitates thorough description of factors in a construction project.

3. The methods of project multi-variant design and multiple criteria analysis improved and adjusted for the developed model - facilitate automated generation of multiple alternatives and integrated assessment of their economic, technical, qualitative and other aspects, as well assist in decision-making.

Approval of the Research Results. The materials related to the dissertation were published in 5 scientific articles.

The results of the dissertation research were presented in one international colloquium and one international scientific conference:

- The 12th German-Lithuanian-Polish Colloquium "Sustainable Development in Civil Engineering and Multi-Attribute Decision Making”: abstracts, 20th24th May 2009, Vilnius, Lithuania;

- International Young Scientists Conference, 29th-30th April 2010, Šiauliai, Lithuania.

Structure of the Dissertation. The dissertation consists of an introduction, four chapters and conclusions, as well as the list of references. There are 6 appendices. The volume is 112 pages (without appendices) with 17 numbered equations, 36 figures and 15 tables. The list of references includes 106 items.

\section{Construction Industry in Times of Economic Recession in} Lithuania and the World

Product sales fluctuations in some areas of construction industry at the level of 20 percent are normal. It has been noted that the cycles of boom and recession typical of the development of construction industry are repeated approximately every ten years (Yisa et al., 1996). Construction companies, treating the given periodicity as a fact of life and a part of reality, are able to prepare for the next downturn during the rise period. They usually adopt the long-term managerial strategies which make it easier to go through hard time (Lovelock, 1997, Sheridan, 1997). 
The conventional analysis of the crisis in the construction and real estate sector analysis is based on economic, legal, institutional and political aspects. For instance, Lu and So (2005) believe that the sudden collapse of Asian holdings during the 1997 financial crisis was the topic of many studies but the larger half of the studies focus on the key principles of economics. In order to overcome the crisis, the demand stimulation measures used by Franklin Roosevelt during the Great Depression in the USA were invoked. However, their effectiveness is questioned by the authors because actually it was the war which helped to overcome depression. Inasmuch as the real estate market is closely related to any economic financial stability, it is expected that the Asian experience can show the way to improve the allocation process of the real estate loans.

The construction and real estate market in Europe is non-homogeneous. The current situation and prospects of each Member State depend on its situation considering needs, demographic trends, the basic economic principles and so on. They also depend on the time when corrections in the real estate market took place as well as on economic openness of a specific country. Finally, they depend on the type of long-term recovery measures to be chosen and on the degree of their successful effect on the entire sector (Detemmerman, 2009).

For example, in Sweden an easily obtained credit, government subsidies and strong economy in the second half of the 1980s resulted in the boom of investments in the construction sector, which reached its peak in 1990 when new residential construction amounted to 69600 . During the crisis of the early 1990 s, there was a decline in construction mainly due to the reform of 19901991 which was aimed at the elimination of state subsidies (Economic sectors: Construction, 2008).

Different methods and models of analysis, forecasting, modelling and management of the crisis in the construction and real estate sector and its segments are applied the world over (Early Warning Systems, neural networks, timeseries analysis, time-varying parameter model, logistic regressions (Logit), a Signal Extraction method, discriminant analysis (DA), a Probit regression model, the back-propagation neural networks model, a support vector machinebased method, a dynamic stochastic general equilibrium model, a vectorautoregressive model, a Bayesian vector autoregressive model). The most successful methods for crises analysis and prediction are complex methods, i.e. combining both, statistical and intellectual methods. In construction and real estate business management, economic research methods must be applied to pricing, financing (loan) and securing performance of obligations.

Various methods and models (Werner, 1994; Bernanke and Gertler, 1999; Goh, 2005; Lu and So, 2005; Bond et al., 2006; Nishiyama, 2006; Ocal et al., 2006; Glascock and Kelly, 2007; Minsky, 2008; Pavlov and Wachter, 2009), e.g. time-series analysis using multiple regression, Box-Jenkins analysis, sea- 
sonality analysis methods; three-index model, time-varying parameter model behavioral macroeconomic portfolio model of international capital flows, postKeynesian models, calibrated macro models, for crisis analysis, forecasting, simulation and management in the construction sector and in separate segments thereof are today being applied worldwide. Some of them are briefly analysed below.

It may be noted that researchers (Werner, 1994; Bernanke and Gertler, 1999; $\mathrm{Lu}$ and So, 2005; Bond et al., 2006; Nishiyama, 2006; Glascock and Kelly, 2007; Minsky, 2008; Pavlov and Wachter, 2009) from various countries engaged in the analysis of crisis in the construction sector but did not consider the research object being analysed by the author of the present research. The latter may be described as follows: a life cycle of a construction industry, and the stakeholders involved as well as micro and macro environment having a particular impact on it making an integral whole. A complex analysis of the research object formulated was made with the help of methods multiple criteria project analysis developed by E. K. Zavadskas and specially adapted by the author for this purpose.

Even the best crises management solutions applicable in other countries cannot be copied blindly.

\section{The Conceptual Model of Construction in Environment of Economic Recession}

A Model for a construction in environment of economic recession was being developed step by step as follows (see Fig. 1):

- A comprehensive quantitative and conceptual description of the construction in environment of economic recession, its stages, interested partiest.

- Development of a complex database based on quantitative and conceptual description of the research object.

- Adaptation of methods of multiple criteria analysis developed by E. K. Zavadskas and A. Kaklauskas (2001) to carry out multivariant design of a construction crisis, determine the utility degree of the alternative versions obtained and set the priorities.

- Development of a Multiple criteria decision support system to be used in computer-aided multivariant design of a construction in environment of economic recession, determining the utility degree of the alternative versions obtained and setting the priorities.

- Multivariant design of construction in environment of economic recession.

- Multple criteria analysis of construction in environment of economic recession.

- Selection of the most rational version of construction in environment of economic recession. 


\section{MACROFA C T OR S}

Economic environment:

market saturation, tax

system, investment climate, pricing
Geographical environment: unusual geographical conditions for those doing business abroad
Legal environment: political environment, legal regulation, level of state regulation

\section{Natural environ-} ment:

water and mineral resources, energy resources

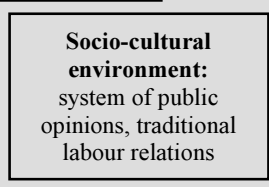

Technological environment: scientific discoveries, innovations, technological changes

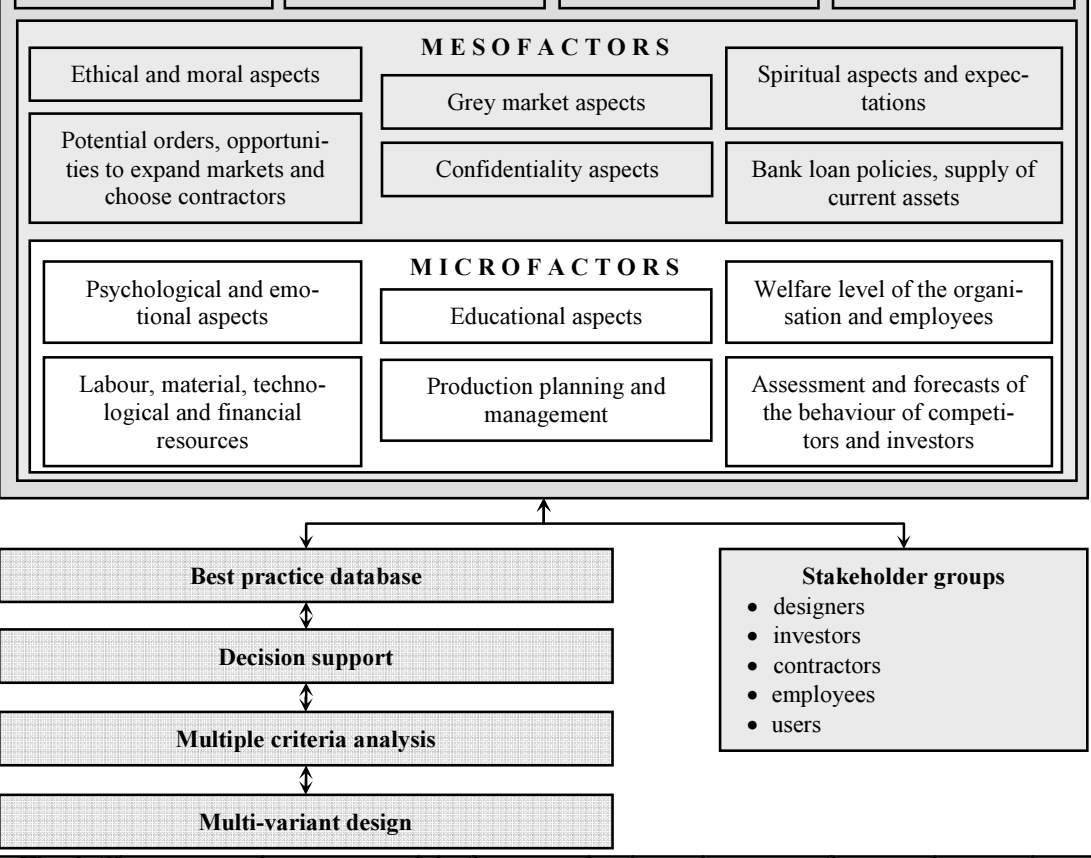

Fig. 1. The suggested concept model of construction in environment of economic recession

- Analysis of micro, meso and macro level environment factors influencing a construction and possibilities to alter them in a desired direction.

- Development of rational micro, meso and macro level environment.

The above model will be now described in more detail.

Any national economic environment is directly affected by tax, monetary, capital flow, investment, lending and interest rate policies enforced by national authorities. Furthermore, economic environment also depends on demand, supply, competition, pricing and other economic factors (Zavadskas et al., 2004). 
The main indicators of an economic environment are cyclic development, inflation and unemployment.

The intensity of bank lending particularly increased in Lithuania between 2004 and 2008. Loans were easily accessible both to construction companies willing to construct apartment buildings or detached/semi-detached houses and to residents seeking their own home (Fig. 2). The data of the Bank of Lithuania shows that 11.2 per cent of Lithuanian households had mortgage loans in 2009. The average loan term was 26 years (Lietuvos bankas, 2010).

The natural environment is the one in which the built and human environment exists. Lithuanian industry of building materials and products (except for the energy industry) consumes the biggest portion of electricity and other types of energy. Lithuanian companies use outdated manufacturing facilities, hence manufacturing of building materials and products is far more energy guzzling than any equivalent in Western Europe.

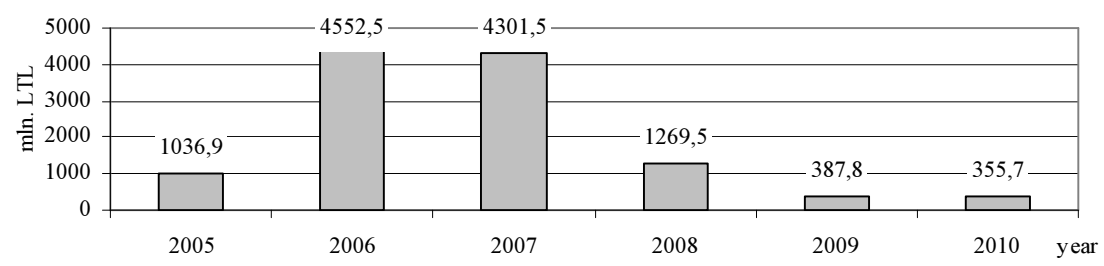

Fig. 2. Mortgage loans

Technological environment. Companies need continuous analysis of potential new technologies and their possible effect on operation. New technologies open new markets and opportunities. The more sophisticated the technology, the more specialised it is. Often not only companies specialise in a narrow technological field but also only some employees within the company are qualified for certain operations. The indispensability factor makes the labour more expensive thus raising the price of products or services.

Socio-cultural environment includes institutions, traditions and other factors that help to shape and perceive the main social values, views and norms of behaviour. Individuals grow in certain societies that shape their key values and beliefs. Settled world-views latter affect individual's relations with other people (Kaklauskas et al. 1998). Labour relations are one of the more significant types of social and cultural interaction. The level of labour relations, career opportunities and use of state-of-the-art technologies help organisations involved in construction and real estate industry make the best of their potential and improve the performance.

The ethical and moral aspects of the global economic crisis were touched upon by the archbishop C. Migliore giving a speech in a session of the UN General 
Assembly in New York in November 2008 (Buika, 2008). Lack of strict accountability rules and insufficient transparency lead to inevitable misuse and negligence. Persons operating in various industries often forget the basic provisions of business ethics. Loan granting to, or insolvency of, a regular client is guarded by strict rules and immediate sanctions, while fat cats often get huge concessions and are gratified ignoring the violations they perpetrate.

Booming sales of real estate were mostly determined by overestimated creditworthiness of buyers and giving in to massive efforts at improvement of living conditions. People often changed their homes succumbing to the influence of others and wishing to stand comparison with their neighbours. Similar psychological aspects prevent revival of normal market relations in times of a crisis. Someone about to buy a dwelling changes the mind just upon hearing talk about possible reorganisation in the workplace or even news about deteriorating economic indicators in a neighbouring country. People fear for their future and abandon planned investments.

Microenvironment mostly encompasses elements in direct relation to the client, the project promoter and users. The micro-level factors, of course, depend on the macro-level factors. For instance, all activities related to building's lifecycle are regulated by a range of laws and norms adopted at the macro-level.

\section{Multi-variant Design and Multiple Criteria Analysis of} Construction in Environment of Economic Recession

Methods for performing multivariant design and multiple criteria analysis of the alternatives developed by E. K. Zavadskas and A. Kaklauskas have been adapted to carry out multivariant design of a construction in environment of economic recession, determine the utility degree of the alternative versions obtained and set the priorities:

- A method of complex determination of the weight of the criteria taking into account their quantitative and qualitative characteristics was adapted. This method allows to calculate and coordinate the weights of the quantitative and qualitative criteria according to the above characteristics.

- A method of multiple criteria complex proportional evaluation of the alternatives enabling the user to obtain a reduced criterion determining complex (overall) efficiency, priority and utility degree of the variant was adapted. This generalized criterion is directly proportional to the relative effect of the values and weights of the criteria considered on the efficiency of the alternative. According to this method the alternatives utility degree are directly proportional to the system of the criteria adequately describing them and the values and weights of these criteria.

- A method of multiple criteria multivariant design of a alternative construction in environment of economic recession enabling the user to make computer-aided 
design of up to 100,000 alternative versions was adapted. Any alternative construction variant obtained in this way is based on quantitative and conceptual information.

Construction opportunities in times of either economic boom or economic recession are compared by solving the problem, which analyses implementation of two equivalent projects - refurbishment of apartment buildings, each with a total floor area of $2.016 \mathrm{~m}^{2}$ - in 2007 and in 2009.

Another problem chosen for the research deals with reconstruction of the park and buildings in a real estate heritage object in the course of four years. The longterm agreement includes work evaluated at almost 9.5 LTL m. In 2010 the project price was indexed with a coefficient 0.8796 , considering the statistical average of Lithuania and ignoring the fact that construction operations in Siauliai anyway cost 10-15 per cent less than at the national level. Because of the particularly strict quality requirements for restoration, the company retained the same wages.

The information used in the analysis is both quantitative and qualitative. The criteria systems for evaluation of construction opportunities at different economic conditions and criteria weights are determined using the integrated method for weight establishment (Zavadskas et al. 2001). Objective weights of quantitative criteria depend on the level of dominance among indicators. The first portion of calculations includes 6 stages:

Stage 1. Calculation of the sum of the values for each quantitative criterion (expressed in LTL).

Stage 2. Calculation of the sum of the values of all quantitative criteria related to the project in question.

Stage 3. Calculation of the weight of each quantitative criterion.

Stage 4. Weights of quantitative and qualitative criteria are matched to come up with the benchmark $\boldsymbol{E}$. Experts chose the price of materials as the benchmark for comparisons of refurbishment projects in apartment buildings, hence for calculations $\boldsymbol{E}_{\boldsymbol{D N M}}=0.422$. In case of the long-term project for restoration of a real estate heritage object, the highest weight is attributed to wages, hence $\boldsymbol{E}_{V P S R}=0.197$.

Stage 5. Expert methods are used to establish the initial weights of qualitative criteria pertaining to projects.

Stage 6. Weights of all qualitative criteria are combined considering the benchmark weight of the quantitative criterion.

When the weights of criteria are already known, multiple criteria analysis methods for projects are employed to estimate the degree of priority and weight of compared options (Zavadskas, 1987; Kaklauskas, 1999; Kaklauskas et al., 2001). The degree of priority and weight is directly and proportionally related to the system of defining criteria for alternatives (both their values and weights). Calculations cover Stages 7-10: 
Stage 7. The initial decision-making matrix $\boldsymbol{D}$ is normalised.

Stage 8. The sums of evaluated normalised minimising indicators $\boldsymbol{S}_{-j}$ (lower value is better, e. g. standard VAT rate, interest rates, etc) and maximising indicators $\boldsymbol{S}_{+j}$ (higher value is better, e. g. GDP growth, tax credits for loan holders, etc) describing the option $j$ are calculated.

Stage 9. Positives $\boldsymbol{S}_{+j}$ and negatives $\boldsymbol{S}_{-j}$ of all compared projects are considered to establish the relative weight of the options $\boldsymbol{Q}_{j}$.

Stage 10. The compared options may vary only slightly, but may also diverge farther apart. The difference is easier to assess when the utility degree of alternatives is known $\boldsymbol{N}_{j}$ (Table 1).

The developed systems of environment factors affecting construction projects provide a thorough description of construction alternatives in diverse circumstances. The systems are used for practical problem solving.

Integrated databases of criteria which define the components of the construction project environment were developed; they define the alternatives of such components both from qualitative and quantitative perspectives.

Table 1. The normalised decision-making matrix for multiple criteria analysis of restoration of a heritage object (manor estate and buildings) and the results

\begin{tabular}{|c|c|c|c|c|c|c|c|}
\hline \multirow[b]{2}{*}{ Criteria } & \multirow{2}{*}{$\begin{array}{l}\text { Measu- } \\
\text { res }\end{array}$} & \multirow{2}{*}{$\begin{array}{l}\text { Min } \\
\text { or } \\
\max \end{array}$} & \multirow{2}{*}{$\begin{array}{l}\text { Weight, } \\
q_{i}\end{array}$} & \multicolumn{4}{|c|}{ Projects in question } \\
\hline & & & & 2007 & 2008 & 2009 & 2010 \\
\hline 1 & 2 & 3 & 4 & 5 & 6 & 7 & 8 \\
\hline GDP increase/decrease & $\%$ & + & 0.052 & 0.0143 & 0.0134 & 0.0111 & 0.0132 \\
\hline Standard VAT rate & $\%$ & - & 0.041 & 0.0097 & 0.0097 & 0.0102 & 0.0113 \\
\hline Interest rates & $\%$ & - & 0.047 & 0.0106 & 0.0114 & 0.0157 & 0.0093 \\
\hline $\begin{array}{l}\text { Tax credits for economic } \\
\text { entities }\end{array}$ & $\begin{array}{l}\text { points } \\
(0 / 10)\end{array}$ & + & 0.052 & 0.0160 & 0.0140 & 0.0120 & 0.0100 \\
\hline Global competitiveness index & place & - & 0.026 & 0.0057 & 0.0065 & 0.0067 & 0.0071 \\
\hline Consumer confidence indicator & $\%$ & + & 0.031 & 0.0107 & 0.0080 & 0.0054 & 0.0069 \\
\hline Average monthly gross wages & LTL & + & 0.188 & 0.0424 & 0.0506 & 0.0484 & 0.0465 \\
\hline Real wage index & $\%$ & + & 0.052 & 0.0146 & 0.0138 & 0.0116 & 0.0120 \\
\hline Unemployment rates & $\%$ & - & 0.041 & 0.0039 & 0.0052 & 0.0159 & 0.0160 \\
\hline Maturity of territorial planning & $\begin{array}{l}\text { points } \\
(0 / 10)\end{array}$ & + & 0.052 & 0.0100 & 0.0120 & 0.0140 & 0.0160 \\
\hline Corruption perception index & $\begin{array}{l}\text { points } \\
(0 / 10)\end{array}$ & + & 0.041 & 0.0102 & 0.0098 & 0.0104 & 0.0106 \\
\hline Entrepreneurship & $\begin{array}{l}\text { Companies } \\
\text { per } 1,000 \\
\text { residents }\end{array}$ & + & 0.047 & 0.0110 & 0.0118 & 0.0122 & 0.0120 \\
\hline $\begin{array}{l}\text { Share of logistics services in } \\
\text { GDP }\end{array}$ & $\%$ & + & 0.052 & 0.0123 & 0.0117 & 0.0133 & 0.0147 \\
\hline Cooperation with academic inst. & points & + & 0.0089 & 0.0090 & 0.0090 & 0.0091 & 0.0089 \\
\hline Share of HT products in exports & $\%$ & + & 0.0096 & 0.0105 & 0.0110 & 0.0100 & 0.0096 \\
\hline Cultural infrastructure & $\begin{array}{l}\text { points } \\
(0 / 10)\end{array}$ & + & 0.0230 & 0.0225 & 0.0146 & 0.0130 & 0.0230 \\
\hline
\end{tabular}


Table 1 continued

\begin{tabular}{|c|c|c|c|c|c|c|c|}
\hline 1 & 2 & 3 & 4 & 5 & 6 & 7 & 8 \\
\hline Social care infrastructure & $\begin{array}{l}\text { points } \\
(0 / 10)\end{array}$ & + & 0.0335 & 0.0239 & 0.0070 & 0.0185 & 0.0335 \\
\hline Heath care infrastructure & $\begin{array}{l}\text { points } \\
(0 / 10)\end{array}$ & + & 0.0386 & 0.0336 & 0.0292 & 0.0336 & 0.0386 \\
\hline Average life expectancy & years & - & 0.0117 & 0.0113 & 0.0103 & 0.0078 & 0.0117 \\
\hline Birth rates & $\begin{array}{l}\text { per } 1,000 \\
\text { residents }\end{array}$ & + & 0.0504 & 0.0556 & 0.0438 & 0.0402 & 0.0504 \\
\hline Added value in construction & $\%$ & + & 0.0089 & 0.0090 & 0.0090 & 0.0091 & 0.0089 \\
\hline Construction confidence indic. & $\%$ & + & 0.0096 & 0.0105 & 0.0110 & 0.0100 & 0.0096 \\
\hline Price indices of construction costs & $\%$ & - & 0.0230 & 0.0225 & 0.0146 & 0.0130 & 0.0230 \\
\hline $\begin{array}{l}\text { Average permits for new non- } \\
\text { residential construction in a quarter }\end{array}$ & number & + & 0.0335 & 0.0239 & 0.0070 & 0.0185 & 0.0335 \\
\hline $\begin{array}{l}\text { Average monthly gross wages } \\
\text { in construction }\end{array}$ & LTL & + & 0.0386 & 0.0336 & 0.0292 & 0.0336 & 0.0386 \\
\hline $\begin{array}{l}\text { Satisfaction of future expecta- } \\
\text { tions }\end{array}$ & $\begin{array}{l}\text { points } \\
(0 / 10)\end{array}$ & + & 0.047 & 0.0176 & 0.0078 & 0.0098 & 0.0118 \\
\hline Job loss anxiety & $\begin{array}{l}\text { points } \\
(0 / 10)\end{array}$ & - & 0.036 & 0.0040 & 0.0120 & 0.0107 & 0.0093 \\
\hline Insufficient income anxiety & $\begin{array}{l}\text { points } \\
(0 / 10)\end{array}$ & - & 0.035 & 0.0067 & 0.0108 & 0.0094 & 0.0081 \\
\hline Sense of security & $\begin{array}{l}\text { points } \\
(0 / 10)\end{array}$ & + & 0.031 & 0.0095 & 0.0072 & 0.0083 & 0.006 \\
\hline Illegal labour relations & $\begin{array}{c}\% \text { of } \\
\text { successful } \\
\text { inspections }\end{array}$ & - & 0.073 & 0.0181 & 0.0191 & 0.0183 & 0.0174 \\
\hline $\begin{array}{l}\text { Opportunities to improve } \\
\text { qualifications }\end{array}$ & $\begin{array}{l}\text { points } \\
(0 / 10)\end{array}$ & + & 0.104 & 0.0331 & 0.0189 & 0.0236 & 0.0284 \\
\hline Competitors in the market & number & - & 0.041 & 0.0086 & 0.009 & 0.0118 & 0.0108 \\
\hline Competitor activity & $\begin{array}{l}\text { points } \\
(0 / 10)\end{array}$ & - & 0.062 & 0.0100 & 0.0160 & 0.0180 & 0.0180 \\
\hline Potential creditors & number & + & 0.083 & 0.0205 & 0.0232 & 0.021 & 0.0183 \\
\hline Creditor capacity & $\begin{array}{l}\text { points } \\
(0 / 10)\end{array}$ & + & 0.114 & 0.0428 & 0.0332 & 0.0142 & 0.0238 \\
\hline $\begin{array}{l}\text { Abidance by the code of } \\
\text { employee ethics }\end{array}$ & $\begin{array}{l}\text { points } \\
(0 / 10)\end{array}$ & + & 0.062 & 0.0149 & 0.0124 & 0.0174 & 0.0174 \\
\hline Employee competencies & $\begin{array}{l}\text { points } \\
(0 / 10)\end{array}$ & + & 0.166 & 0.0361 & 0.0361 & 0.0433 & 0.0505 \\
\hline Employee experience & $\begin{array}{l}\text { points } \\
(0 / 10)\end{array}$ & + & 0.218 & 0.0503 & 0.0503 & 0.0587 & 0.0587 \\
\hline Employee loyalty & $\begin{array}{l}\text { points } \\
(0 / 10)\end{array}$ & + & 0.083 & 0.0119 & 0.0198 & 0.0237 & 0.0277 \\
\hline Proactive employees & $\begin{array}{l}\text { points } \\
(0 / 10)\end{array}$ & + & 0.093 & 0.0140 & 0.0232 & 0.0279 & 0.0279 \\
\hline Respected deadlines & $\begin{array}{l}\text { points } \\
(0 / 10) \\
\end{array}$ & + & 0.114 & 0.0236 & 0.0275 & 0.0314 & 0.0314 \\
\hline Quality guarantees in supply & $\begin{array}{l}\text { points } \\
(0 / 10)\end{array}$ & + & 0.135 & 0.0312 & 0.0312 & 0.0363 & 0.0363 \\
\hline $\begin{array}{l}\text { Matching of interests among } \\
\text { parties }\end{array}$ & $\begin{array}{l}\text { points } \\
(0 / 10)\end{array}$ & + & 0.093 & 0.0279 & 0.0232 & 0.0232 & 0.0186 \\
\hline
\end{tabular}


Table 1 continued

\begin{tabular}{|l|c|c|c|c|c|c|c|}
\hline \multicolumn{1}{|c|}{1} & 2 & 3 & 4 & 5 & 6 & 7 & 8 \\
\hline Wages & LTL & + & 0.197 & 0.0492 & 0.0492 & 0.0492 & 0.0492 \\
\hline Materials & LTL & + & 0.184 & 0.0494 & 0.0489 & 0.0395 & 0.0461 \\
\hline Machinery & LTL & + & 0.012 & 0.0041 & 0.0040 & 0.0032 & 0.0007 \\
\hline Overhead costs & LTL & + & 0.101 & 0.0274 & 0.0273 & 0.0247 & 0.0217 \\
\hline Profits & LTL & + & 0.029 & 0.0101 & 0.0101 & 0.0088 & 0 \\
\hline VAT & LTL & - & 0.099 & 0.0253 & 0.0251 & 0.0239 & 0.0247 \\
\hline Sum of maximising normalised evaluated indicators $S_{+j}$ & 0.7979 & 0.7799 & 0.7423 & 0.7580 \\
\hline Sum of minimising normalised evaluated indicators $S_{-j}$ & 0.1501 & 0.1683 & 0.1788 & 0.1747 \\
\hline Weight of the fund absorption option $Q_{j}$ & 0.9651 & 0.9381 & 0.8973 & 0.9188 \\
\hline Priority of the fund absorption option $P_{j}$ & $\mathbf{1}$ & $\mathbf{2}$ & $\mathbf{4}$ & $\mathbf{3}$ \\
\hline
\end{tabular}

The practical problem helped to determine the utility degree and priority of construction options in refurbishment of apartment buildings or restoration of a cultural heritage object. Construction had the best conditions and the most favourable environment in 2007, when the utility degree of both projects was equal to 100 per cent.

\section{Recommendable System for Construction in Environment of Economic Recession}

Based on the analysis of existing information, knowledge, expert and decision support systems and in order to determine most efficient versions of construction crisis management a Construction in Environment of Economic Recession (CEER) System consisting of a database, database management system, modelbase, model-base management system and user interface was developed (Figure 3).

\begin{tabular}{|l|l|}
\hline \multicolumn{1}{|c|}{ User } \\
\hline \multicolumn{1}{|c|}{\begin{tabular}{l}
\multicolumn{1}{c|}{ Model bases: } \\
\hline User interface \\
\hline $\begin{array}{l}\text { Construction macro-environment DB } \\
\text { Construction meso-environment DB } \\
\text { Construction micro-environment DB } \\
\text { DB of values and weights }\end{array}$
\end{tabular}$\quad \begin{array}{l}\text { Model for initial data of components in } \\
\text { construction environment } \\
\text { Model for multiple criteria analysis of } \\
\text { construction environment } \\
\text { Model for utility degrees and priorities of } \\
\text { components in construction environment } \\
\text { Multiple criteria model for multi-variant design } \\
\text { of components in construction environment } \\
\text { Recommendable model }\end{array}$} \\
\hline
\end{tabular}

Fig. 3. Components of the CEER system

The presentation of information needed for decision making in CEER system may be in conceptual (digital (numerical), textual, graphical (diagrams, graphs, drawing, etc), photographical, sound, visual (video)) and quantitative forms. Thus, quantitative information presentation involves criteria systems and 
subsystems, units of measurement, values and initial weights fully defining the variants provided. Conceptual information means a conceptual description of the alternative solutions, the criteria and ways of determining their values and weights, etc.

In this way, CEER system enables the decision maker to get various conceptual and quantitative information on construction in environment of economic recession from a database and a model-base allowing him to analyze the above factors and make an efficient solution.

The following tables make CEER system database:

- Initial data tables. These contain general facts about the construction in environment of economic recession considered.

- Tables assessing construction in environment of economic recession solutions. They contain quantitative and conceptual information about alternative construction in environment of economic recession solutions.

- Tables of multivariant design. They provide quantitative and conceptual information on the interconnection of the construction in environment of economic recession elements, their compatibility and possible combinations as well as data on complex multivariant design of a construction in environment of economic recession.

To design the structure of a database and perform its completion, storage, editing, navigation, searching, browsing, etc a database management system was used.

The tables of refurbishing variant assessment contain the variants available and their quantitative and conceptual description. Quantitative description of the alternatives deals with the systems and subsystems of criteria fully defining the variants as well as the units of measurement and values and initial weights. Conceptual description defines the alternatives available in a commonly used language giving the reasons and providing grounds for choosing a particular criterion, calculation its value, weight and the like. The process of drawing up the tables of variant assessment consists of the following steps:

- collection and presentation of general information about the variants under consideration,

- establishment and conceptual description of the systems and subsystems of criteria,

- establishing of criteria for choosing the units of measurement,

- estimation of the values of the criteria with the description of the process of calculation and its presentation,

- determination of the initial weights of the criteria with the description of the process of calculation and its presentation. 
In order to design and realise an effective construction crisis management project the alternatives available should be analysed. Computer-aided multivariant design requires the availability of the tables containing the data on the interconnection of the elements and the solutions made as well as their compatibility, possible combination and multivariant design.

When using a method of multivariant design addapted by the author until 100000 alternative construction in environment of economic recession alternatives may be obtained. These versions are checked for their capacity to meet various requirements. Those which can not satisfy these requirements raised are excluded from further consideration. In designing a number of variants of construction crisis management the problem of significance compatibility of the criteria arises. In this case, when a complex evaluation of the alternatives is carried out the value of a criterion weight is dependent on the overall criteria being assessed as well as on their values and initial weights.

Since the efficiency of a construction crisis management variant is often determined taking into different factors a model-base of a decision support system should include models enabling a decision maker to do a comprehensive analysis of the variants available and make a proper choice. The following models of model-base are aimed to perform this function:

- a model for determining the initial significances of the criteria (with the use of expert methods),

- a model for the criteria significance establishment,

- a model for multivariant design of a construction in environment of economic recession,

- a model for multiple criteria analysis and setting the priorities,

- a model for determination of project utility degree,

- a model for providing recommendations.

Based on the above models, a CEER system can make until million construction in environment of economic recession alternative versions, performing their multiple criteria analysis, determining utility degree and selecting most beneficial variant without human interference.

According to the user's needs, various models may be provided by a model base management system. When a certain model (i.e. determining the initial weights of the criteria) is used the results of the calculations obtained become the initial data for some other models (i.e. a model for multivariant design of a construction crisis management, a model for multiple criteria analysis and setting the priorities), while the results of the latter, in turn, may be taken as the initial data for some other models (i.e. determining project utility degree, providing recommendations, etc). 
A management system of the CEER model base provides the user with a model base allowing him to modify the models available, eliminating those which are no longer needed and adding some new models linked with the existing ones.

The more alternative versions are investigated before making a final decision, the greater is the possibility to achieve a more rational end result. Basing oneself on possessed information and the CEER system it is possible to perform multiple criteria analysis of construction crisis management components and select the most efficient versions. After this, the received compatible and rational components of a construction crisis management are joined up into integrated alternative. Having performed multiple criteria analysis of construction crisis management made up in such a way, one can select the most efficient ones. Strong and weak sides of investigated alternatives are also given an analysis. Facts of why and by what degree one version is better than the other are also established. All this is done basing oneself on conceptual and quantitative information.

\section{General Conclusions}

1. The analysis of studies done worldwide suggests that a number of intelligent systems look into the effect of the economic crisis on financial or banking sectors. The general effect of micro, meso and macro-environment factors on the construction industry and business opportunities in environment of economic recession has not been studied before.

2. The author applied the theory of complex systems and multiple criteria analysis methods and developed an original model of construction in environment of economic recession. The model facilitates detailed description of the environment of construction at different levels and assessment of its effect on the performance.

3. The CEER model was successfully used to solve practical problems, hence its adequacy is proven.

4. The CEER model helps to determine the utility degree (like $N_{D N M}-100 \%$ and $90,07 \%$ ) and priority (like $P_{V P S R}-1>2>4>3$ ) of environment variants in construction industry through an integrated assessment of positive and negative aspects of the alternatives in question.

5. The developed recommendable system for construction in environment of economic recession facilitates integrated analysis of the process behind construction projects, also its components, the stakeholders involved and the pertaining external environment. The system is universal and may be used to handle a range of theoretical and practical problems in construction. It may be used by many stakeholder groups: investors, contractors, users, etc. 
6. The developed criteria system of the environment of construction helps to analyse and assess the feasibility of construction and reconstruction projects. Using the developed integrated knowledge base of the environment of construction industry, the system facilitates integrated analysis of the environment both from quantitative and qualitative perspectives.

7. The CEER system provides guidance to interested groups example to construction company (development activities) or investor (deciding on the investment of time and conditions).

\section{List of Published Works on the Topic of the Dissertation}

\section{In the reviewed scientific periodical publications}

Kaklauskas, A.; Zavadskas, E. K.; Bagdonavičius, A.; Kelpšienè, L.; Bardauskienè, D.; Kutut, V. 2010. Conceptual modelling of construction and real estate crisis with emphasis on comparative qualitative aspects description, Transformations in Business \& Economics 9(1): 42-61. ISSN 1648-4460 (ISI Web of Science).

Kaklauskas, A.; Kelpsiene, L.; Zavadskas, E. K.; Bardauskiene, D.; Kaklauskas, G.; Urbonas, M.; Sorakas, V. 2011. Crisis management in construction and real estate: Conceptual modeling at the micro-, meso- and macro-levels / Original Research Article, Land Use Policy 28(1): 280-293. ISSN 02648377 (ISI Web of Science).

Kelpšienè, L.; Matusevičienė, M. L. 2009. Bendros ekonominė krizès itakos statybos imonei tyrimas, Jaunuju mokslininku darbai 3(24): 49-57. ISSN 1648-8776 (CEEOL, Index Copernicus).

Petrosius, J.; Kelpsiene, L. 2010. Overview of reaction to the economic crisis in construction and real estate modelling, Jaunuju mokslininku darbai 1(26) 106-115. ISSN 1648-8776 (CEEOL, Index Copernicus).

\section{About the Author}

Loreta Kelpšienè was born on 15 September 1969 in Jieznas, Prienai District. In 1994 she graduated with a bachelor's degree from Šauliai Faculty of Kaunas University of Technology, where she also obtained the qualification of a certified civil engineer in 1995. In 2005 she graduated Vilnius Gediminas Technical University and was granted a master's degree in civil engineering. In 2008 Loreta Kelpšienè became a certified lecturer in Šiauliai University. In 2007-2011 - PhD student of Vilnius Gediminas Technical University. 


\section{STATYBOS ŠAKOS EKONOMINIO NUOSMUKIO SĄLYGOMIS MODELIAVIMAS}

Tiriamoji problema. Tiriamają problemą sudaro statybos projektų igyvendinimo ekonominio nuosmukio sąlygomis vertinimas, geriausių metodų ir priemonių, kuriuos statybos imonès turètų naudoti, tikintis išlikti ir parduoti savo produkciją ar paslaugas, nustatymas taikant informacines ir intelektines technologijas.

Darbo aktualumas. Statybą veikia skirtingo lygio veiksniai, kurie gali būti ivvairiai grupuojami. Statybos ekonominio nuosmukio aplinkoje modelio kūrimas ir inovacijos:

- Suinteresuotoms grupèms (investuotojams, statybos imonèms, projektuotojams, tiekejams, valstybinèms institucijoms, naudotojams ir kt.) suteikia galimybę îvardinti ir aprašyti statybą veikiančią aplinka,

- padeda įvertinti projektu igyvendinimo galimybes ir priimti sprendimus,

- nustato rizikingiausius veiksnius, darančius neigiamą itaką statybos rezultatui, leidžia laiku imtis prevencijos priemonių; ivertina perspektyviausias ar rizikingiausiai i̇monès veiklos ar plètros sritis,

- mažina darbo santykių stresa, didina darbo ir investicijų efektyvumą.

Tyrimu objektas. Tyrimų objektą sudaro veiksniai darantys itaką statybai valstybès, visuomenès ir i̇monès lygiu, šiame procese dalyvaujančios suinteresuotos grupès bei jų siekiamybès.

Darbo tikslas - sukurti statybos šakos ekonominio nuosmukio sąlygomis modelį ir jo pagrindu intelektinę sistemą, ivvertinčią ir apibūdinčią statybos tendencijas, taikant sukurtą statybos esant bendriems ekonomikos sunkumams modeli.

Darbo uždaviniai. Tikslui pasiekti reikia išspręsti tokius uždavinius:

1. Atlikti pasaulyje sukurtų metodų, modelių ir intelektinių sistemų analizę. Išanalizuoti Lietuvos ir užsienio patirti priimant statybos sprendimus ekonominio nuosmukio aplinkoje, taikant naujausias internetines, intelektines ir kitas technologijas bei inovacijas (1 skyrius).

2. Sukurti statybos esant bendram ekonomikos nuosmukiui koncepcinį modelị.

3. Sukurti kriterijų sistema, išsamiai apibūdinančią statybos esant bendriems ekonomikos sunkumams aplinką (2 skyrius).

4. Statybos ekonominio nuosmukio sąlygomis modeli pritaikyti praktiškai.

5. Atlikti statybos esant bendriems ekonomikos sunkumams aplinkos variantini projektavimą ir daugiakriterinę analizę (3 skyrius).

6. Modelio pagrindu sukurti rekomendacinę statybos ekonominio nuosmukio aplinkoje intelektinę sistemą (4 skyrius). 
7. Nustatyti geriausius metodus ir priemones, kuriuos statybos imonès, veikiančios bendro ekonominio nuosmukio aplinkoje, turètų naudoti, tikintis išlikti ir parduoti savo produkciją ar paslaugas (4 skyrius).

Tyrimu metodika. Tyrimo metodikos paremtos Lietuvos ir užsienio šalių mokslininkų šioje srityje atliktų darbų analize. Atliktiems tyrimams pritaikyti ir papildyti daugiakriterinès analizès metodai, informacinès technologijos, analogijos principai, lyginamosios analizės, logikos ir sintezės metodai.

Rengiant darbą remtasi Lietuvos ir užsienio autorių mokslinèmis bei kitomis publikacijomis, enciklopediniais žinynais, specializuotais žodynais, statistiniais leidiniais, ỉvairiu šalių statistiniais duomenimis internete, kitais Lietuvos ir užsienio mokslo institucijų moksliniais bei informaciniais leidiniais.

\section{Darbo mokslinis naujumas ir jo reikšmé}

1. Sukurtas originalus statybos, kaip ūkio šakos, ekonominio nuosmukio aplinkoje daugiakriterinis modelis, išsamiai aptarti jo elementai.

2. Sukurtam statybos ekonominio nuosmukio aplinkoje (SENA) modeliui buvo pritaikyti jau sukurti projektu variantinio projektavimo ir daugiakriterinès analizès metodai, kuriuos patobulinus buvo kompleksiškai ịvertinti jo ekonominiai, techniniai, kokybiniai ir kiti aspektai.

3. Detaliai aprašyti makro-, meso- ir mikroaplinkos veiksniai, veikiantys SENA. Pateikta šiu veiksnių itaka SENA.

4. Praktiškai realizuotas statybos ekonominio nuosmukio aplinkoje modelio.

5. Sukurta kriterijų sistema, išsamiai apibūdinanti statybos aplinką esant ekonominiam nuosmukiui.

6. Sukurta duomenų bazè, išsamiai apibūdinanti statybos projekto aplinką ekonominio nuosmukio sąlygomis.

7. Sukurta rekomendacinè statybos ekonominio nuosmukio sąlygomis supančios aplinkos intelektinè sistema (3 skyrius).

8. Praktiškai realizuota sukurta intelektinès statybos ekonominio nuosmukio salygomis supančios aplinkos daugiavariantinè sprendimų paramos sistema (4 skyrius).

Darbo rezultatu praktinè reikšmè. Sukurta originali rekomendacinè statybos ekonominio nuosmukio aplinkoje sistema, kuri gali būti taikoma priimant efektyvius statybos projektų valdymo sprendimus. Sistemos teikiamomis galimybèmis gali naudotis įvairios suinteresuotos grupès - investuotojai, rangovai, statybinių medžiagų gamintojai, projektuotojai, naudotojai ir kt. Tyrimų rezultatai buvo panaudoti Šiaulių universiteto mokymo procese rengiant paskaitas (Statybos verslas) vadybos specialybès su statybos specializacija magistrantams. 


\section{Ginamieji teiginiai}

1. Sukurtas statybos ekonominio nuosmukio aplinkoje modelis leidžia adekvačiai aprašyti suinteresuotų statybos dalyvių lūkesčius bei rinka, juos veikiančią išorinę makro, meso ir mikro aplinką kaip vieną visumą ir padèti priimant efektyvų sprendimą.

2. Sukurta statybos apsunkintomis ekonominėmis salygomis duomenų bazé leidžia išsamiai apibūdinti statybos projekto veiksnius.

3. Sukurtam statybos ekonominio nuosmukio aplinkoje modeliui pritaikyti ir patobulinti projektų variantinio projektavimo bei daugiakriterinès analizès metodai leidžia automatizuotu būdu sudaryti daugybę alternatyvų, kompleksiškai įvertinti jų ekonominius, techninius, kokybinius ir kitus aspektus bei padèti priimant sprendimą.

Darbo rezultatų aprobavimas. Disertacijos tema išdèstyta medžiaga skelbta 5 mokslo publikacijose. Disertacijoje atliktų tyrimų rezultatai buvo paskelbti tarptautiniame koliokviume ir tarptautineje mokslineje konferencijoje:

- The 12th German-Lithuanian-Polish Colloquium "Sustainable Development in Civil Engineering and Multi-Attribute Decision Making", May 20-24, 2009 Vilnius, Lithuania;

- International Young Scientists Conference, 29-30 April 2010, Šiauliai, Lithuania.

Disertacijos struktūra. Disertaciją sudaro įvadas, keturi skyriai ir išvados bei 6 priedai. Darbo apimtis - 112 puslapiu (be priedu), tekste panauda 17 numeruotų formulių, 36 paveikslai ir 15 lentelių. Naudotasi 106 literatūros šaltiniais.

\section{Bendrosios išvados}

1. Pasaulinių tyrimų analizè parodè, kad daugelis intelektinių sistemų tiria bendros ekonominès krizès itaką finansų ar bankiniu sistemu srityje. Bendro mikro-, mezo- ir makroaplinkos veiksniu poveikio statybos sektoriui ir verslo galimybėms ekonominio nuosmukio aplinkoje netyrinèta.

2. Remiantis sudètingų sistemų teorija ir daugiakriterinès analizės modeliais, autorès sukurtas originalus statybos ekonominio nuosmukio aplinkoje modelis. Jis leidžia vartotojui detaliai apibūdinti statybos aplinką skirtingais lygiais ir įvertinti jos poveikị veiklos rezultatams.

3. Sukurta kriterijų sistema, apibūdinanti statybos esant bendriems ekonomikos sunkumams aplinką. Kriterijų skaičius svyruoja nuo 47 iki 52, ir gali būti koreguojamas pagal vartojo poreikius. Sprendžiant konkrečius uždavinius (daugiabučių namų modernizavimo ir vilos parko ir statinių rekonstrukcijos) irodytas SENA modelio tinkamumas.

4. SENA modelis leidžia nustatyti statybos aplinkos variantų naudingumo laipsni (pvz., $N_{D N M}-100 \%$ ir 90,07\%) ir prioritetiškumą (pvZ., $P_{V P S R}-$ 
$1>2>4>3$ ), kompleksiškai ịvertinus nagrinėjamų alternatyvų teigiamas bei neigiamas savybes.

5. Sukurta rekomendacinė statybos ekonominio nuosmukio aplinkoje daugiakriterinè sistema sudaro sąlygas kompleksiškai analizuoti statybos projektų igyvendinimo procesa, sudetines jo dalis, jame dalyvaujančias suinteresuotas grupes ir veikiančią išorinę aplinką. Ši sistema yra universali ir gali būti taikoma įvairiems statybos teoriniams bei praktiniams uždaviniams spręsti, ja gali naudotis ívairios suinteresuotos grupès: investuotojai, rangovai, tiekejjai, projektuotojai, naudotojai, pritaikydami savo tikslams.

6. Sukurta statybos aplinkos kriterijų sistema leidžia analizuoti bei vertinti statybos ir rekonstrukcijos projektu igyvendinimo galimybes. Remiantis sukurta statybos šakos makro-, mezo- ir mikroaplinkos kompleksine žinių duomenų baze, sistema sudaro salygas kompleksiškai analizuoti aplinką kiekybine bei kokybine formomis.

7. SENA sistema teikia rekomendacijas suinteresuotoms grupèms, pavyzdžiui, statybos imonei (tobulinant veikla) arba investuotojui (apsisprendžiant dèl investavimo laiko bei salygu).

\section{Trumpai apie autorę}

Loreta Kelpšienè gimè 1969 m. rugsèjo 15 d. Jiezne, Prienų rajone. 1994 m. baigè bakalauro studijas Kauno technologijos universiteto Šiaulių fakultete, o $1995 \mathrm{~m}$. ten pat igijo diplomuoto statybos inžinieriaus kvalifikaciją. 2005 m. Vilniaus Gedimino technikos universitete jai buvo suteiktas statybos inžinerijos magistro laipsnis. Nuo $2004 \mathrm{~m}$. Loreta Kelpšienè dirbo asistentu Šiaulių universitete, o nuo 2008 m. iki dabar dirba lektoriumi. 2007-2011 m. Vilniaus Gedimino technikos universiteto doktorantas. 